\title{
Studies on the flies occurring from the excrement of pasturing cattle and other herbivorous animals. 3. On the 3rd stage larvae of the genus Morellia R.-D. from Japan (Diptera : Muscidae)*
}

\author{
Satoshi SHINONAGA** and Rokuro KANO** \\ ** Department of Medical Zoology, Faculty of Medicine, Tokyo Medical and \\ Dental University, 1-5 Yushima, Bunkyo-ku, Tokyo 113, Japan
}

(Received: June 6, 1974)

\begin{abstract}
The 3rd stage larvae of 4 species belonging to the genus Morellia R.-D. from Japan are described and figured. Those are $M$. saishuensis Ôchi, $M$. hortensia (Wiedemann), M. hortorum (Fallén), and M. aenescens R.-D. External characters of those species are similar each other, however, posterior spiracles of saishuensis, and shape and size of anterodorsol spines in each species are characteristic. Those are most useful characters for identification of Morellia-larvae. The larva of M. saishuensis is newly described in this paper.
\end{abstract}

\section{INTRODUCTION}

Flies belonging to the genus Morellia are known to occur from cow or waterbuffalo dung in Japan. Hitherto 4 species of Morellia were recorded from Japan (Shinonaga and Kano, 1971, 1973, 1974). Of these, $M$. hortorum and $M$. aenescens are Palaearctic species and distributed in northern part of Hokkaido in Japan. M. hortensia is Oriental species and distributed in south of Tokara Islands in Japan, and $M$. saishuensis is distributed in Palaearctic East Asia, such as U.S.S. R., China, Korea and Japan. The larvae of $M$. hortensia was described by Thomson (1947) and Fan (1957), but the larvae of the other species are not described in detail in contrast with their adults. On the puparium, Stork (1936) described 2 species, $M$. aenescens and $M$. hortorum. In the description, he refered to the shape of

* This investigation was partly supported by the research grant of the Ministry of Education, Japanese Government.

**篠永 哲, 加納六郎：東京医科歯科大学医学部医 動物学教室（干 113 東京都文京区晹島 1-5-45） posterior spiracles and spines of abdomen. In the present paper, the authors described the 3rd stage larvae of 4 species which were obtained from the reared adults.

\section{Method of Collecting LaRvae}

Method of collecting larvae was made by the Shinonaga's method of 1973 (Shinonaga and Kano, 1973). M. hortorum and $M$. aenescens were obtained in Toyotomi, northern part of Hokkaido; M. saishuensis in Chiba city; and $M$. hortensia in Yona, Okinawa main island.

\section{General Characters AND IDENTI- FICATION OF THE LARVAE OF Morellia IN JAPAN}

Fully matured larvae of the genus are if to $10 \mathrm{~mm}$ in length. External features of Morellia-larvae are not similar to the other larvae belonging to Muscidae. The body is comparatively sclerotized and yellowish brown in color. Each segment has a spine band on anterior and posterior margins (Fig. 1 ), and the spines are different in shape, number and size in each species (Figs. 14-17). 


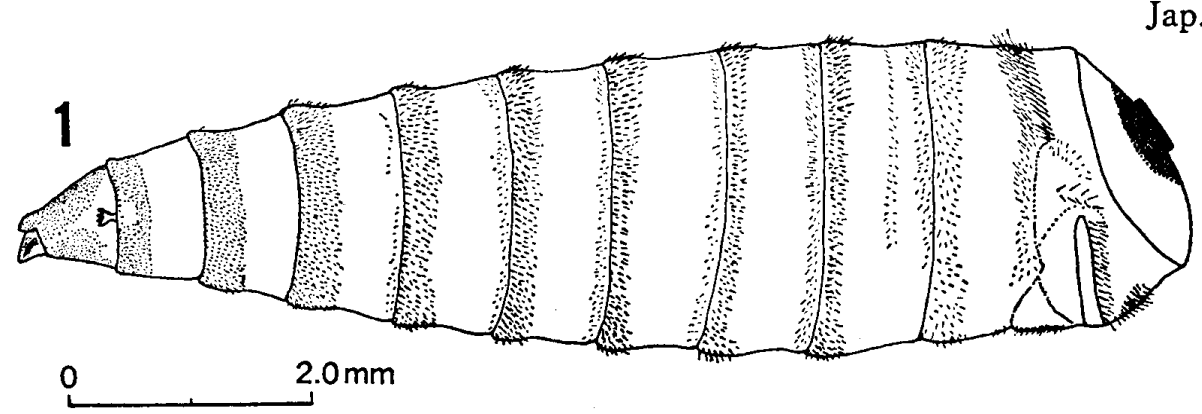

Fig. 1 Lateral view of 3rd stage larvae of saishuensis
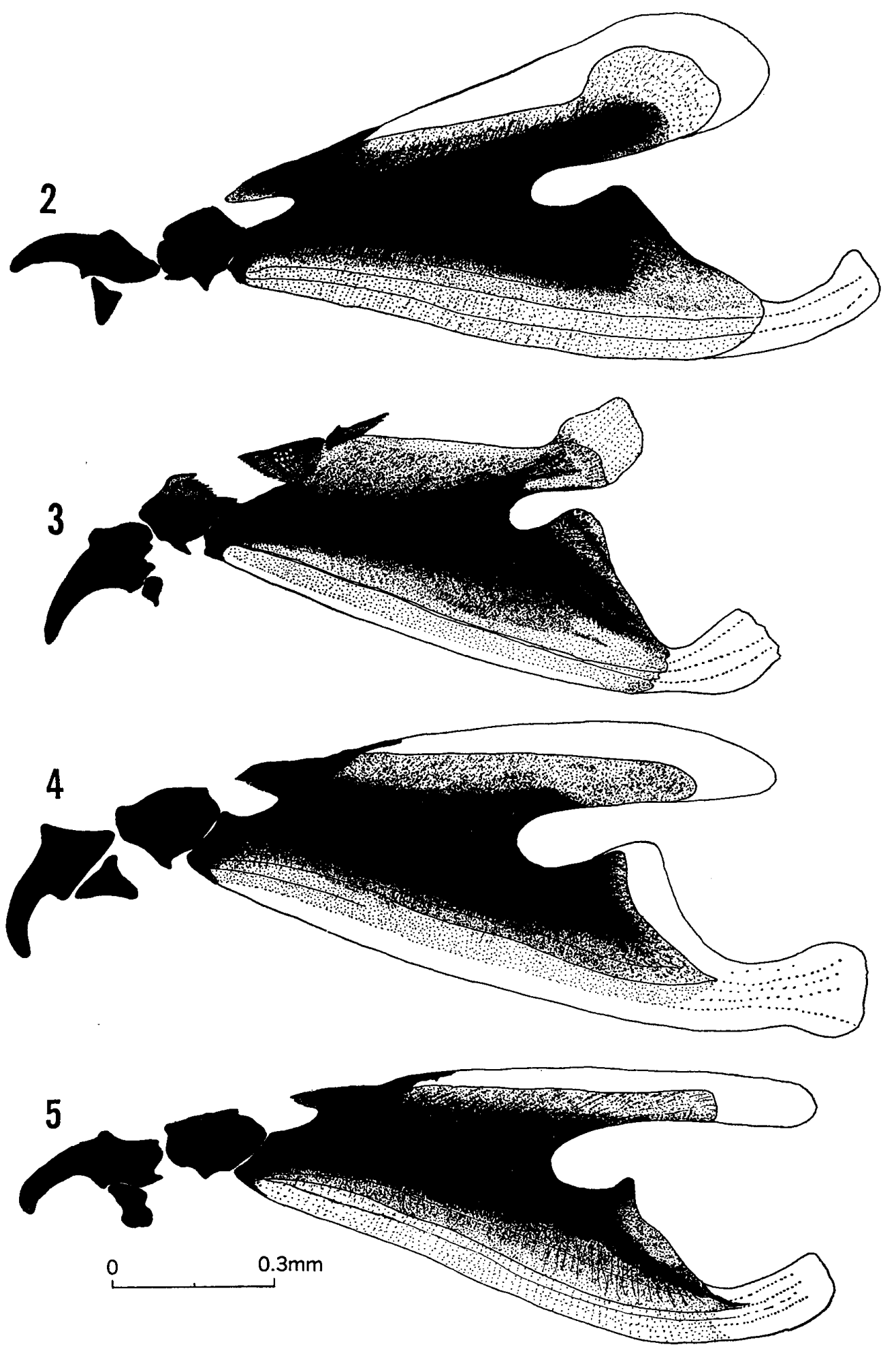

Figs. 2-5 Lateral view of cephalopharyngeal sclerite

2. saishuensis; 3 . hortensia; 4. hortorum; 5 . aenescens. 


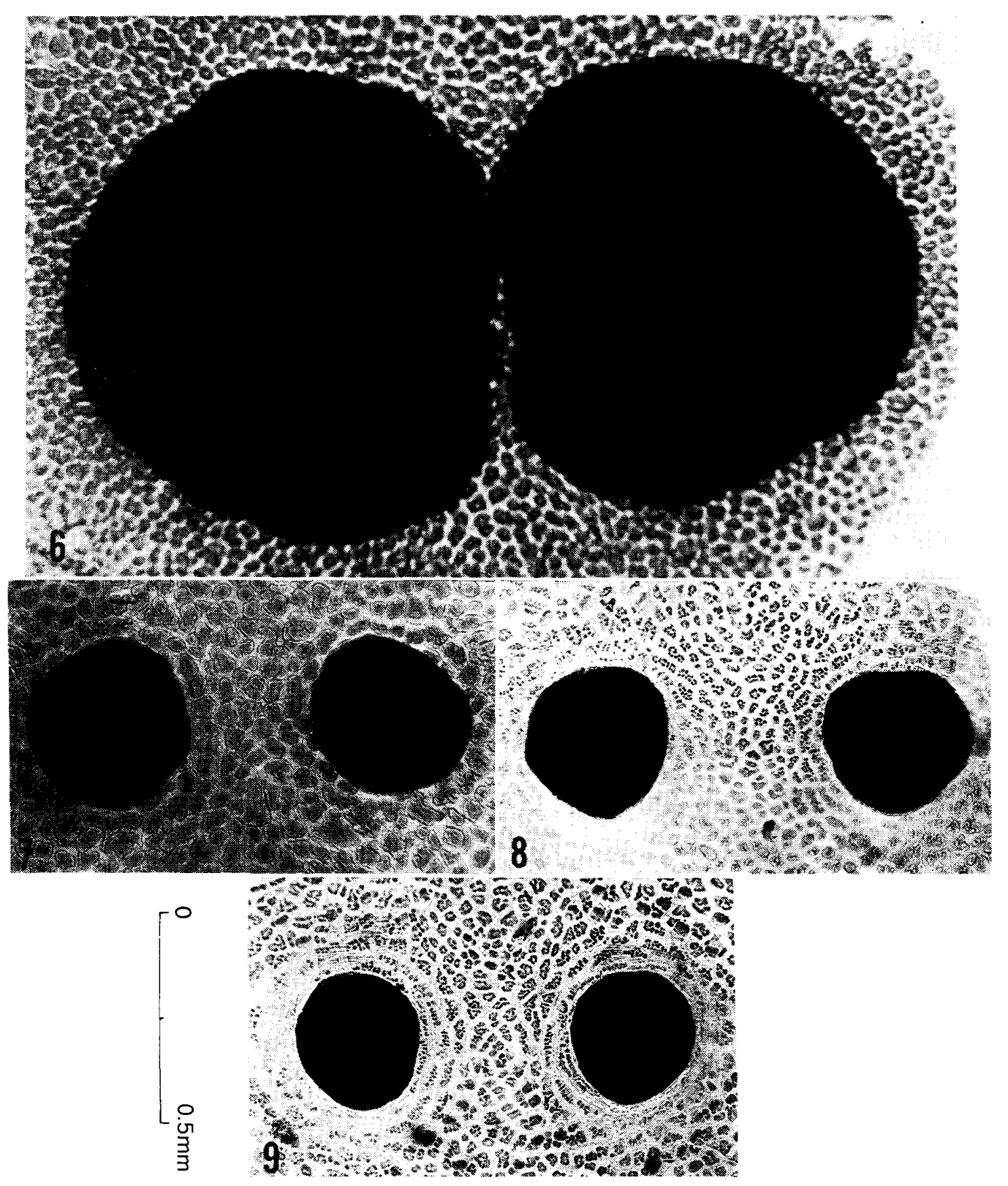

Figs. 6-9 Posterior view of posterior spiracles

6. saishuensis: 7. hortensia: 8. hortorum: 9. aenescens.

Anterior spiracles divided into 4 to 7 branches (Figs. 10-13). Anal plate is narrow and has no spines. Papillae around anal plate are reduced. Posterior end of the body is diagonally truncated as in Fig. 1. Posterior spiracles are heavily sclerotized and have three curved slits (Figs. 6-9). Cephalopharyngeal sclerite is not so much different in each species (Figs. 2-5). Mouth hooks of both sides are symmetric, and accessory sclerite is usually absent. Ventral cornua of pharyngeal sclerite is longer than dorsal cornua and has triangular projection on the middle part.

The larvae of Morellia-species in Japan are closely related each other, but $M$. saishuensis has a characteristic posterior spiracles. Those are heavily sclerotized and surrounded by the area (Figs. 1 and 6). Number of branches of anterior spiracles is not so good character for identification. Number of branches in saishuensis and hortensia are usually 4 , and 5 to 7 in hortorum and crenescens. However, sometimes the number is different in both sides. The most useful character to separate each larva is shape and size of spines on anterior margin in each segment (Figs. 14-17). The figures showed the dorsal spines on 6th segment for comparison of each species. The spines are 


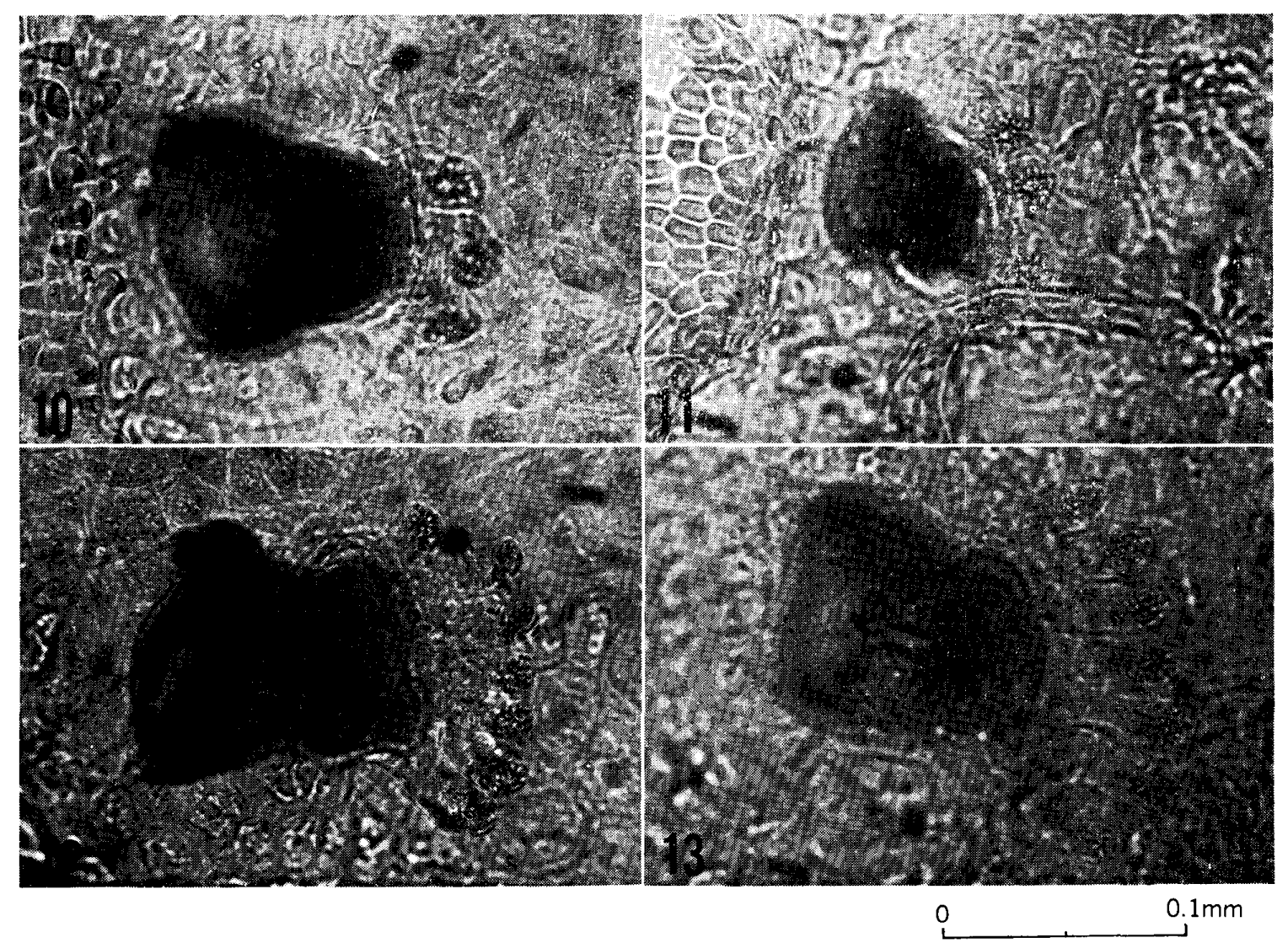

Figs. 10-13 Lateral view of anterior spiracles

10. saishuensis; 11. hortensia; 12. hortorum; 13. aenescens.
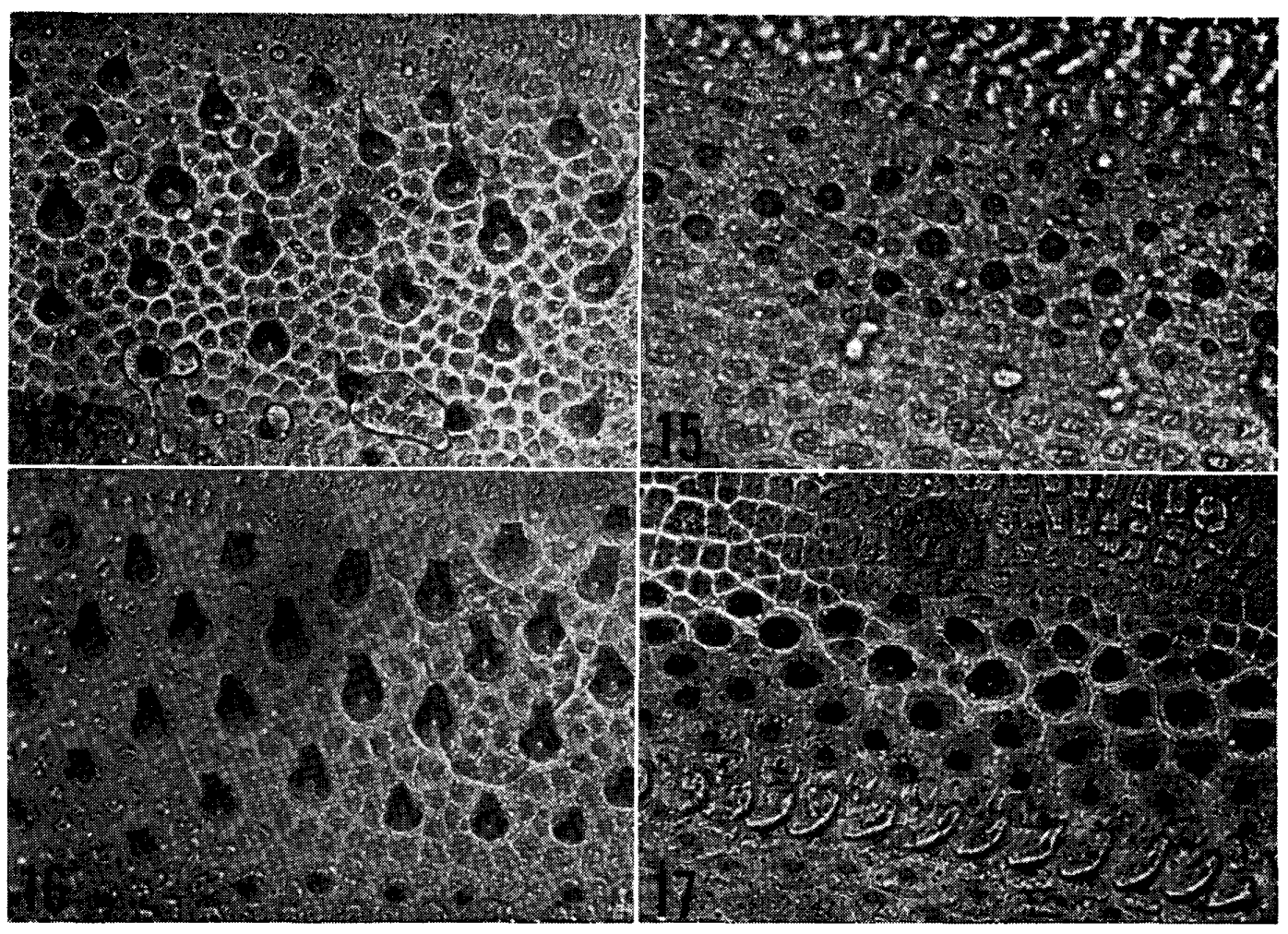

0

$0.2 \mathrm{~mm}$

Figs. 14-17 Dorsal spines on 6th segment

14. saishuensis; 15. hortensia; 16. hortorum; 17. aenescens. 
uniform throughout the body. The spines are large and tapering in saishuensis; large and truncated in hortorum; small and round in hortensia and aenescens as shown in figures (Figs. 14-17). Spines of hortensia are smaller than those of aenescens. Stork (1936) has described on the spines of $M$. aenescens and said that the spines between the seventh and eighth segments on the dorsal side are small and inconspicuous, on the ventral side, however, clean and very numerous. Stork's descriptions were confirmed again by the authors. Thomson (1937) and Zimin (1948, 1951) described the spines of $M$. simplex, but it differs from saishuensis in shape of the spines on thoracic segment. Cephalopharyngeal sclerite is not characteristic in each species, however, posterior end of dorsal cornua is protruding upward in saishuensis and hortensia and straight in hortorum and aenescens. From the results of the study, it was known that the shape and size of spines on segments are the most characteristic and useful character for the identification of Morellia-larvae of Japan.

\section{REFERENCES}

Fan, T. (1957): Notes on the third stage larvae of synanthropic flies in Shanghai district. Acta Ent. Sinica, 7(4) : 405-422 (in Chinese).

Shinonaga, S. and R. Kano (1971) : Fauna Japonica, Muscidae I (Insecta, Diptera). pp. 38-45, 215-217. Keigaku Publ. Co., Tokyo.

Shinonaga, S. and R. Kano (1973): Studies on the flies occurring from excrement of pasturing cattle and other herbivorous animals. 1 . On the 3rd stage larvae of the genus Orthellia of
Japan (Diptera, Muscidae, Muscinae). Jap. J. Sanit. Zool., 24 (1): 57-63.

Shinonaga, S. and R. Kano (1974) : On the larvae of genus Morellia from Japan. Jap. J. Sanit. Zool., 24 (4) : 303 (in Japanese).

Stork, M. N. (1936) : Contribution to the knowledge of the puparia of Anthomyiidae. Tijd. Ent. 79 : 94-168.

Thomson, R. C. M. 1937): Observation on the biology and larvae of the Anthomyiidae. Parasitology, 29 31 : 271-358.

Thomson. R. C. M. (1947): Notes on the breeding habits and early stages of some muscids associated with cattle in Assam. Proc. Roy. Ent. Soc. Lond., Ser. A, 22:89-100.

Zimin, L. S. (1948) : Identification of the larvae of synanthropic flies in Tadzhikistan. Fauna SSSR, $28: 75-77$.

Zimin. L. S. (1951) : Fauna USSR, 18(4) :213222.

$$
\begin{gathered}
\text { 摘 要 } \\
\text { 牛およびその他の草食獣糞から発生する } \\
\text { 蠅類に関する研究 } \\
\text { 3. 日本産セジロハナバェ属の } \\
\text { 終令幼虫について }
\end{gathered}
$$

日本産セジロ八ナバェ属については, 篠永・加納 （1971）が成虫 4 種を記載している，わが国では，本属 の八エはすべて牛または水牛算から発生するが，このら ちでも放牧地の牛粪からの発生が主である。

著者らは，野外で採集した雌成虫に産卵させて 3 令㭃 虫を得, これについて記載した。本属の幼虫は, 他のイ エバエ科幼虫と比較して形態が異なり，体の後端は斜に 切断された形（図 1) で外皮はかなり強く硬化してい る.また，各節に柬帯を有し，この棘の大きさと形は種 の特徴よして重要であり，これにより種の同定が可能で ある。 